\title{
Real and illusory perceptions of patients in induced coma
}

\author{
Percepções reais e ilusórias de pacientes em coma induzido \\ Percepciones reales e ilusorias de pacientes en coma inducido
}

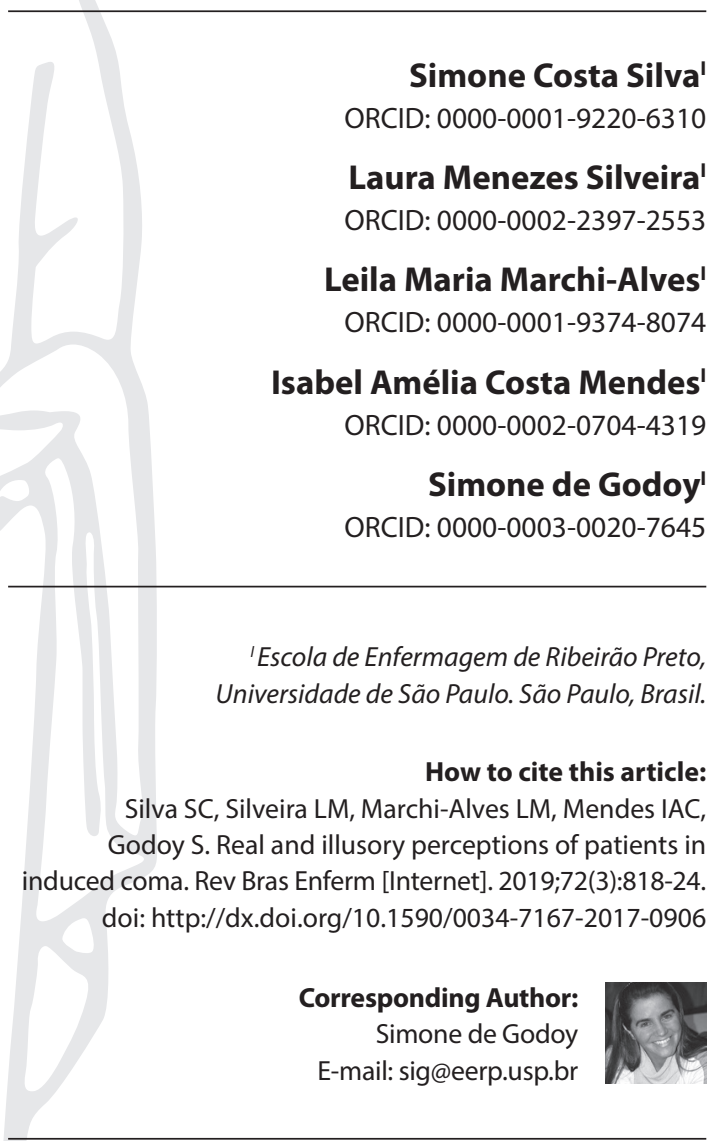

Submission: 01-19-2018 Approval: 02-26-2019

\begin{abstract}
Objective: To identify, in the scientific literature, real and illusory perceptions of adult patients in induced coma. Methods: This is an integrative review of 15 primary studies from the Medline, Web of Science, LILACS, CINAHL and SCOPUS databases. Results: The main memories reported after induced coma were thirst, cold, and pain. In some studies, patients reported they were unable to tell whether they were awake or dreaming, whether it was real or unreal. Satisfactory memories were reported by patients related to the care received and the use of bedside journals. Conclusion: Evidence showed a number of studies aiming to identify delirium, but without a focus on analyzing real or illusory perceptions of patients after induced coma. Thus, this integrative review identified scientific evidence of memories related to perceptions of sedated patients in the intensive care unit.

Descriptors: Deep Sedation; Memory; Delirium; Critical Care; Nursing.
\end{abstract}

\section{RESUMO}

Objetivo: Identificar, a partir da literatura científica, percepções reais e ilusórias de pacientes adultos em coma induzido. Método: Revisão integrativa de 15 estudos primários localizados nas bases de dados Medline, Web of Science, LILACS, CINAHL e SCOPUS. Resultados: As principais memórias relatadas após o coma induzido são sede, frio e dor. Há estudos em que os pacientes afirmaram não distinguir se estavam acordados ou sonhando, se o que acontecia era real ou irreal. Identificaram-se relatos de memórias satisfatórias relacionadas ao cuidado recebido e ao uso de diários de cabeceira. Conclusão: As evidências mostraram um leque de estudos direcionados a identificar o delirium, porém com menor foco na identificação da percepção real ou ilusória do paciente após coma induzido. Desse modo, esta revisão integrativa proporcionou a identificação de evidências científicas sobre as memórias relativas à percepção do paciente sedado e em estadia na Unidade de Terapia Intensiva.

Descritores: Sedação Profunda; Memória; Delírio; Cuidados Críticos; Enfermagem.

\section{RESUMEN}

Objetivo: Identificar, a partir de la literatura científica, percepciones reales e ilusorias de pacientes adultos en coma inducido. Método: Revisión integrativa de 15 estudios primarios alojados en las bases de datos Medline, Web of Science, LILACS, CINAHL y SCOPUS. Resultados: Los recuerdos más reportados luego del coma inducido son sed, frío y dolor. Existen estudios en los que los pacientes afirmaron no distinguir si estaban despiertos o soñando, si era real o irreal. Se identificaron relatos de recuerdos satisfactorios relacionados al cuidado recibido y al uso diario de cabecera. Conclusión: Las evidencias mostraron un abanico de estudios cuyo objetivo era identificar el delirium, aunque con menor enfoque en la identificación real o ilusoria del paciente luego del coma inducido. Así, esta revisión integrativa consiguió identificar evidencias científicas acerca de los recuerdos relativos a la percepción del paciente sedado e internado en la Unidad de Terapia Intensiva. Descriptores: Sedación Profunda; Memoria; Delirio; Cuidados Críticos; Enfermería. 


\section{INTRODUCTION}

In clinical practice, a coma generates many doubts, fears, and curious facts, not only due to the way it happens, but especially regarding the perceptions of individuals in this condition. There are two types of coma: physiological and induced coma, and in general, it is defined as a state in which a person is unable to properly respond to the external environment as a result of reduced neural activities ${ }^{(1)}$. For the National Institute of Neurological Disorders and Stroke, a coma is a deep state of unconsciousness from which an individual has not been awakened. During this period, higher brain functions are lost while other key functions such as breathing are intact. ${ }^{(2)}$.

An induced coma, or sedation as physicians call it, occurs with the administration of sedative drugs that reduce brain function and maintain vital functions with the help of technologies available for the treatment of critical patients. Sedation is indicated for the control of anxiety and pain, use of mechanical ventilation, and as an adjuvant therapy for patients with traumatic brain injury (TBI), when reducing brain function is necessary to prevent edema and increased intracranial pressure ${ }^{(3)}$.

In order to assess the level of consciousness of a comatose patient, the Glasgow Coma Scale (GCS) was developed to conduct a neurological evaluation when the patient is in a physiological coma. For a drug-induced coma, this evaluation can be performed using scales that assess the level of sedation. The scale that demonstrates the best psychometric properties is the Richmond Agitation-Sedation Scale (RASS), also indicated to check for delirium - in this case, it is applied before the Confusion Assessment Method for the Intensive Care Unit (CAM-ICU) ${ }^{(4)}$.

A recent study showed that delirium is common in critical ICU patients and related to more advanced age and use of sedative and/ or analgesic drugs such as midazolam, propofol, and morphine ${ }^{(5)}$.

Although delirium is an acute neurological and cognitive disorder that occurs for a short period, its early identification is important and, in general, nurses are the professionals who identify it as they are aware of the factors associated with it. In addition, nurses can implement nonpharmacological measures for the prevention and identification of delirium with the use of valid instruments, such as the CAM-ICU(5).

Instruments for delirium assessment have been validated in Brazil and worldwide. In Brazil, the most frequently used delirium assessment tool is the Confusion Assessment Method (CAM) and its revised versions, which are based on criteria from the Diagnostic and Statistical Manual of Mental Disorders, 5 th edition (DSM-5).This document recommends that a scale for this type of evaluation should address four items: specific delirium validation, ability to distinguish delirium from dementia, evaluation of multiple characteristics related to delirium, and feasibility of use in patients with delirium ${ }^{(6)}$.

In this context, besides the concerns about determining the coma stage of ICU patients, attention should be dedicated to the patients' sensory recovery, especially when sedatives have been used to induce a coma. Although sedation and analgesia are used to ensure comfort and anxiety relief in patients on mechanical ventilation, intensive treatment associated with the use of sedatives can stress patients, produce illusory memories and trigger psychological changes. One study showed that among patients receiving a continuous infusion of sedatives, about $47 \%$ had memories of real events and $34 \%$ had illusory memories, and such facts were also related to the severity of the disease, period on mechanical ventilation, and ICU length of stay ${ }^{(7)}$.

Given the scenario above, real and illusory perceptions of patients in an induced coma should be analyzed to guide the adoption of actions to help patients'sensory recovery and improve the clinical management of these individuals, since the lack of knowledge about this subject compromises the adoption of care strategies, mainly by nurses and the nursing team, who monitor patients the most during a hospital stay ${ }^{(8)}$.

Addressing this ICU clinical practice challenge is directly associated with having a better understanding of an induced coma in patients who have been submitted to this procedure for treatment reasons. Considering the above, a scientific literature review is important to recognize how real and illusory perceptions of adult patients in an induced coma have been described.

\section{OBJECTIVE}

To identify, in the scientific literature, real and illusory perceptions of adult patients in an induced coma.

\section{METHOD}

This is an integrative review of the literature, whose design enables to search, assess and synthesize evidence available about a certain theme, aiming to incorporate its results into clinical activities. This study comprised the following steps: theme identification and development of the guiding question, search of primary studies, definition of the information to be extracted, evaluation of studies included in the review, interpretation, synthesis, and reporting of results ${ }^{(9-10)}$.

The PICO strategy was used to formulate the guiding question for this study, where $P$ refers to the study population (adult patients); I means the studied intervention or the variable of interest (induced coma); C refers to the comparison to another intervention (not the case in this study); and O refers to the outcome of interest (identification of real and illusory perceptions). Thus, the guiding question of this integrative review was: What are the real and illusory perceptions of adult patients in an induced coma?

The search for identification of articles was conducted in May 2017 by two authors of this integrative review, with the support of a librarian, in the following databases: LILACS (Latin American and Caribbean Center on Health Sciences Information), MEDLINE (Medical Literature Analysis and Retrieval System Online), CINAHL (Cumulative Index to Nursing and Allied Health Literature), Web of Science, and SCOPUS. The following controlled descriptors from the Medical Subject Headings (MeSH) and Health Sciences Descriptors (DeCS) were used:"sedação profunda/deep sedation, delírio/delirium, memória/memory, critical care, nursing", articulated with the uncontrolled keyword 'intensive therapy'and Boolean operators AND and OR.

A total of 269 studies were identified, four of which were removed due to duplicity. Following the selection and eligibility criteria, articles in English, Portuguese and Spanish published up to ten years before the search in journals addressing the perceptions of adult patients in an induced coma were included; whereas articles published in congress annals, literature reviews, editorials, opinion articles, and response letters were excluded. A total of 106 articles were evaluated, 
91 of which were excluded as they focused on the perception of the family or the interdisciplinary team, rather than the patient's, so the sample of this review included 15 articles (Figure 1).
In order to complement the data available in the articles, the level of evidence was identified according to the design of each study. The studies were classified according to levels of evidence, where level I referred to systematic reviews or meta-analyses of relevant randomized controlled trials (RCTs) or clinical guidelines, based on systematic reviews of RCTs; level Il was derived from one or more properly delineated RCTs; level III referred to properly designed non-randomized clinical trials; level IV was related to case-control studies or cohort of proper design; level $V$ referred to evidence from systematic reviews of qualitative and descriptive studies; level VI referred to descriptive or qualitative studies; and level VII was derived from the opinion of authorities and/ or reports of expert committees ${ }^{(10)}$.

\section{RESULTS}

The final sample consisted of 15 articles (Chart 1). Regarding the language, 14 (94.4\%) articles were in English. The largest concentration of articles was in 2013, when five (33.3\%) articles were published, followed by 2014 with three (20\%), and 2015 and 2007 with two each (13.4\%). Three studies were conducted in Sweden (20\%), 40\% in Australia, Canada,
A validated instrument ${ }^{(12)}$ was used in the extraction of data from the studies included in this review.

The selected articles were read by two different researchers and synthesized according to the following aspects: year of publication, language, country where the study was conducted, authors and journals, study design, level of evidence, conducted with adult patients in an induced coma, number of participants, with evaluation of delirium and/or memory after intensive care. Due to a divergence in the evaluation of two eligible articles, another researcher from this review acted as a judge reading both articles and extracting the information for study inclusion. and Denmark - two in each country, $40 \%$ in the United States, Brazil, Finland, Norway, Australia/New Zealand and Switzerland - one in each country. The journal with the highest number of published articles was the Intensive and Critical Care Nursing with three (20\%) articles, followed by the American Journal of Critical Care with two (13.3\%), the Australian Critical Care with two (13.3\%), and the Journal of Clinical Nursing, also with two (13.3\%) articles.

Regarding the level of evidence, 11 (73.4\%) articles were classified as level VI. As for the study design, eight (53.3\%) were qualitative, four (26.7\%) were prospective, and three (20\%) were descriptive (Chart 2).

Chart 1 - Characteristics of the articles included in this integrative review according to the year of publication, author, title, journal, and country. Ribeirão Preto - SP, 2017

\begin{tabular}{|c|c|c|c|c|}
\hline Year & Author & Title of study & Journal & Country \\
\hline 2016 & $\begin{array}{l}\text { Svenningsen } \mathrm{H} \text {, Egerod I, } \\
\text { Dreyer } \mathrm{P}^{(13)} \text {. }\end{array}$ & $\begin{array}{l}\text { Strange and scary memories of the intensive care unit: } \\
\text { a qualitative, longitudinal study inspired by Ricoeur's } \\
\text { interpretation theory. }\end{array}$ & $\begin{array}{l}\text { Journal of Clinical Nursing } \\
25: 2807-2815\end{array}$ & Denmark \\
\hline 2015 & $\begin{array}{l}\text { Fink RM, Makic MBF, } \\
\text { Poteet AW, Oman KS }{ }^{(14)} \text {. }\end{array}$ & The ventilated patient's experience. & $\begin{array}{l}\text { Dimensions of Critical Care Nursing } \\
\text { 34: } 301-308\end{array}$ & USA \\
\hline 2015 & $\begin{array}{l}\text { Whitehorne K, Gaudine A, } \\
\text { Meadus R, Solberg }{ }^{(15)} \text {. }\end{array}$ & $\begin{array}{l}\text { Lived experience of the intensive care unit for patients } \\
\text { who experienced delirium. }\end{array}$ & $\begin{array}{l}\text { American Journal of Critical Care } \\
24: 474-479\end{array}$ & Canada \\
\hline 2014 & $\begin{array}{l}\text { Clukey L, Weyant AR, } \\
\text { Roberts } \mathrm{M} \text {, Henderson } \mathrm{A}^{(16)} \text {. }\end{array}$ & $\begin{array}{l}\text { Discovery of unexpected pain in intubated and } \\
\text { sedated patients. }\end{array}$ & $\begin{array}{l}\text { American Journal of Critical Care } \\
\text { 23: } 216-220\end{array}$ & Canada \\
\hline 2014 & $\begin{array}{l}\text { Costa JB, Marcon SS, } \\
\text { Macedo CRL, Jorge AC, } \\
\text { Duarte PAD } \\
\end{array}$ & $\begin{array}{l}\text { Sedation and memories of patients subjected to } \\
\text { mechanical ventilation in an intensive care unit. }\end{array}$ & $\begin{array}{l}\text { Revista Brasileira de Terapia Intensiva } \\
\text { 26: } 122-129\end{array}$ & Brazil \\
\hline 2014 & $\begin{array}{l}\text { Ewens B, Chapman R, } \\
\text { Tulloch A, Hendricks JM }{ }^{(17)} \text {. }\end{array}$ & $\begin{array}{l}\text { ICU survivors' utilisation of diaries post discharge: a } \\
\text { qualitative descriptive study. }\end{array}$ & $\begin{array}{l}\text { Australian Critical Care } \\
27: 28-35\end{array}$ & Australia \\
\hline
\end{tabular}




\begin{tabular}{|c|c|c|c|c|}
\hline Year & Author & Title of study & Journal & Country \\
\hline 2013 & $\begin{array}{l}\text { Meriläinen } \mathrm{M} \text {, Kyngäs } \mathrm{H} \text {, } \\
\text { Ala-Kokko } \mathrm{T}^{(18)} \text {. }\end{array}$ & $\begin{array}{l}\text { Patients' interactions in an intensive care unit and their } \\
\text { memories of intensive care: A mixed method study. }\end{array}$ & $\begin{array}{l}\text { Intensive and Critical Care Nursing } \\
\text { 29: 78-87 }\end{array}$ & Finland \\
\hline 2013 & $\begin{array}{l}\text { Engström A, Nyström N, } \\
\text { Sundelin G, Rattray J(19). }\end{array}$ & $\begin{array}{l}\text { People's experiences of being mechanically ventilated } \\
\text { in an ICU: a qualitative study. }\end{array}$ & $\begin{array}{l}\text { Intensive and Critical Care Nursing } \\
\text { 29: } 88-95\end{array}$ & Sweden \\
\hline 2013 & Svenningsen $\mathrm{H}^{(20)}$. & $\begin{array}{l}\text { Associations between sedation, delirium and post- } \\
\text { traumatic stress disorder and their impact on quality } \\
\text { of life and memories following discharge from an } \\
\text { intensive care unit. }\end{array}$ & $\begin{array}{l}\text { Danish Medical Journal } \\
60: 1-22\end{array}$ & Denmark \\
\hline 2013 & $\begin{array}{l}\text { Akerman } \mathrm{E} \text {, Ersson } \mathrm{A} \text {, } \\
\text { Fridlund } \mathrm{B} \text {, Samuelson } \mathrm{K}^{(21)} \text {. }\end{array}$ & $\begin{array}{l}\text { Preferred content and usefulness of a photodiary as } \\
\text { described by ICU patients - a mixed method analysis. }\end{array}$ & $\begin{array}{l}\text { Australian Critical Care } \\
\text { 26: } 29-35\end{array}$ & Australia \\
\hline 2011 & Samuelson $\mathrm{KAM}^{(22)}$. & $\begin{array}{l}\text { Unpleasant and pleasant memories of intensive care } \\
\text { in adult mechanically ventilated patient - findings } \\
\text { from } 250 \text { interviews. }\end{array}$ & $\begin{array}{l}\text { Intensive and Critical Care Nursing } \\
27: 76-84\end{array}$ & Sweden \\
\hline 2009 & Storli SL, Lind R ${ }^{(23)}$. & $\begin{array}{l}\text { The meaning of follow-up in intensive care: patients' } \\
\text { perspective. }\end{array}$ & $\begin{array}{l}\text { Scandinavian Journal of Caring } \\
\text { Science } \\
23: 45-56\end{array}$ & Norway \\
\hline 2008 & $\begin{array}{l}\text { Engström A, Grip K, } \\
\text { Hamrén } \mathrm{M}^{(24)} \text {. }\end{array}$ & $\begin{array}{l}\text { Experiences of intensive care unit diaries: touching a } \\
\text { tender wound. }\end{array}$ & $\begin{array}{l}\text { Nursing in Critical Care } \\
14: 61-67\end{array}$ & Sweden \\
\hline 2007 & $\begin{array}{l}\text { Roberts BL, Rickard CM, } \\
\text { Rajbhandari D, Reynolds } \mathrm{P}^{(25)} \text {. }\end{array}$ & $\begin{array}{l}\text { Factual memories of ICU: recall at two years post- } \\
\text { discharge and comparison with delirium status during } \\
\text { ICU admission - a multicenter cohort study. }\end{array}$ & $\begin{array}{l}\text { Journal of Clinical Nursing } \\
\text { 16: } 1669-1677\end{array}$ & $\begin{array}{l}\text { Australia } \\
\text { and New } \\
\text { Zealand }\end{array}$ \\
\hline 2007 & Roulin MJ, Hurst S, Spirig R $\mathrm{R}^{(26)}$. & Diaries written for ICU patients. & $\begin{array}{l}\text { Qualitative Health Research } \\
\text { 17: 893-901 }\end{array}$ & Sweden \\
\hline
\end{tabular}

Chart 2 - Distribution of articles of this integrative review according to their level of evidence, study design, number of participants, and perceptions identified. Ribeirão Preto - SP, 2017.

\begin{tabular}{|c|c|c|c|}
\hline $\begin{array}{c}\text { Level of } \\
\text { evidence }\end{array}$ & Study design & $\begin{array}{l}\text { Number of } \\
\text { participants }\end{array}$ & Perceptions identified \\
\hline VI & Qualitative & 10 patients & Memories of delirium, fear, and insecurity ${ }^{(13)}$. \\
\hline $\mathrm{VI}$ & Qualitative & 14 patients & $\begin{array}{l}\text { Memory of intubation and uncontrolled pain, even with the administration of sedative and } \\
\text { analgesic drugs }{ }^{(14)} \text {. }\end{array}$ \\
\hline $\mathrm{VI}$ & Qualitative & 4 patients & Self-memories as external to themselves ${ }^{(15)}$. \\
\hline $\mathrm{VI}$ & Qualitative & 24 patients & The use of a bedside journal enabled the recovery of consistent memories ${ }^{(16)}$. \\
\hline IV & Prospective cohort & 152 patients & Reduced factual memory of delusional patients in relation to non-delusional patients ${ }^{(8)}$. \\
\hline $\mathrm{VI}$ & Qualitative & 18 patients & Memory of fear and perception of death ${ }^{(17)}$. \\
\hline IV & Prospective cohort & 115 patients & The use of abedside journal supported memory recovery ${ }^{(18)}$. \\
\hline IV & Prospective cohort & 641 patients & Delirium was detected in $65 \%$ of patients during the first interview in the ICU ${ }^{(19)}$. \\
\hline $\mathrm{VI}$ & Descriptive & 8 patients & $\begin{array}{l}\text { Bedside journals allowed patients to recover memories of the disease, treatment, reactions of } \\
\text { the patient, and the presence and support of professionals } \mathrm{s}^{(20)} \text {. }\end{array}$ \\
\hline $\mathrm{VI}$ & Descriptive & $\begin{array}{c}84 \text { patients } \\
77 \text { family members }\end{array}$ & Memories of pain, no correlation with the perception of the family member ${ }^{(21)}$. \\
\hline $\mathrm{VI}$ & Descriptive & 250 patients & $\begin{array}{l}\text { Pleasant memories of care, stress relief, and distressing memories of physical suffering and } \\
\text { perceptive distress }{ }^{(22)} \text {. }\end{array}$ \\
\hline $\mathrm{VI}$ & Qualitative & 325 patients & $\begin{array}{l}\text { Memories of delirium in a face-to-face interview after two weeks and in a telephone interview after } \\
\text { two and six months were a mixture of fiction and facts actually experienced by the patient }{ }^{(23)} \text {. }\end{array}$ \\
\hline IV & Prospective cohort & 128 patients & Memory of ICU experience, combining real and illusory events ${ }^{(24)}$. \\
\hline $\mathrm{VI}$ & Qualitative & 9 patients & $\begin{array}{l}\text { A beside journal provided information about events of which the patients had fragmented } \\
\text { memories }^{(25)} \text {. }\end{array}$ \\
\hline $\mathrm{VI}$ & Qualitative & 8 patients & $\begin{array}{l}\text { Memories of dependence on other people, dependence on technology as if the body was not } \\
\text { able to function }{ }^{(26)} \text {. }\end{array}$ \\
\hline
\end{tabular}

Among the perceptions identified, the most common was delirium in seven (46.7\%) studies, followed by appreciation of a bedside journal as a memory aid in four $(26.7 \%)$ studies, pain and fear in two $(13.4 \% \%)$, pleasant memories in one (6.7\%), and feeling of dependence in one (6.7\%).

\section{DISCUSSION}

In hospital services, ICU patients require more complex care when compared to other hospital sectors, as their clinical conditions are severe and they need critical support and treatment, 
using advanced technologies for therapies, diagnoses, and special care. In this scenario, the need for sedation is essential in most treatments ${ }^{(27)}$.

Regarding sensory perception, studies indicate that hearing is the last sense to be lost in comatose patients. However, even with the advancement of neuroscience, it is still not possible to determine what actually happens and what is perceived by individuals in this state. Therefore, it is very important to be careful with noise around patients, when talking to other professionals at the bedside, and to communicate verbally with patients before any procedure, even when they are in a coma ${ }^{(4)}$.

In terms of hearing, the presence of a family member and their statements to the patient in a coma have been very important. Words of affection, encouragement and especially religious messages are the most frequent statements of relatives to ICU patients. It is believed that when a familiar voice says the patient's name or a message, the resulting stimulus is greater, as people tend to pay more attention to facts that have cognitive and emotional value ${ }^{(28-29)}$.

Human sensory organs need to be constantly regulated to capture relevant events as one's processing ability and response channels have limits. These limitations cause a constant competition for central nervous system processing channels, which consider every context and experience and the complexity of synaptic connections, where the stimulus can be characterized and received with attention or indifference ${ }^{(30)}$.

Intensive care can be stressful, with memories of unrealistic facts, distressing memories and the detection of stressors during the ICU stay, which may also cause post-discharge psychological disorders, also known as post-traumatic stress disorder (PTSD) ${ }^{(8)}$.

According to the literature, the main memories reported after an induced coma are thirst, cold and pain. The patients stated they could not distinguish whether they were awake or dreaming, whether it was real or unreal. As for external perceptions, they reported an unpleasant feeling of receiving care when they were under treatment, as they felt fully dependent on other people and technologies. Also, hearing perceptions about the health condition and the reason for the patient's hospitalization show another aspect that should be considered by the nursing team when communicating with another professional in the sector ${ }^{(18)}$.

A study ${ }^{(23)}$ showed that patients with prior experience in the ICU reported that such fact remains in their memories, so one way to ease this stress is to fill in the gaps of the unreal with real facts. For this reason, the researchers used a bedside journal in the study, which was written by nurses and complemented with photos in an attempt to reorganize the reflection and memories of patients after discharge. When asked about their ICU stay, they felt it easier when the bedside journal was presented to them, putting the experiences together, joining the elements in a true and realistic way.

Data from a multicenter study conducted in the United States collected 239 memories of patients after discharge from an intensive care unit for evaluation and showed distressing and delusional feelings among the patients, $83 \%$ of them had accurate memories of the sedation period, and the visit of relatives was the most common perception reported by them ${ }^{(31)}$.

In this integrative review, the studies that assessed perceptions of patients in intensive care confirmed the patients had perceptions of what was happening to them and around them while in an induced coma. However, gaps are still observed in how real perceptions are measured since methods have been proposed to describe only unreal perceptions or delirium. Also, some unpreparedness of the team was identified when delivering patient care, with professionals often acting as if the patient had no hearing, tactile and even visual perception ${ }^{(31)}$.

Reports of patients who experienced delirium during their ICU stay emphasize they felt as if they were in a bubble and that nobody could help or listen to them from the outside. Some patients reported they heard music, sea waves, or had visions of dark or colorful tunnels; others felt like sailing on a ship. They also reported they felt they could be in several places such as a race track, a beauty salon, a building, a nightclub, describing in detail the characteristics of each place ${ }^{(15)}$.

Given the context of several perceptions of patients in a postinduced coma, nursing has been the frontline support, providing explanations about all interventions to be performed, relieving anxiety, emphasizing that quality care has driven satisfactory memories of patients during intensive care ${ }^{(25)}$.

One approach developed in a multicenter study conducted in New Zealand and Australia showed patient reports of memories of distress and fear; on the other hand, patients detailed memories of the nursing staff and described explanations nurses provided them. However, poor communication, lack of privacy and noise were still identified. Despite some anecdotal reports provide by some patients, most of them (83\%) have factual and clear memories of their ICU stay ${ }^{(25)}$.

Another study ${ }^{(32)}$ showed the importance of using communication tools with ICU patients, emphasizing the use of non-verbal communication methods. The authors suggest pads, scales to measure pain and observation of signs and facial expression of patients, which can be interpreted according to the variability of vital signs. They also emphasize the need for intensive care nurses to be alert to signs of delirium during care, using methods and language that facilitates the communication of recurring events related to the patient's clinical condition to family members, physicians, and the interdisciplinary team, also considering the emotional and psychological condition of family members.

The results of the synthesized articles showed patient perceptions of care received in the ICU, reports of distress and pain, lack of correlation between the patients' feelings and those reported by their relatives, and the nursing team view of delirium and strategies to encourage the recovery of memories and their association with the experiences during the ICU stay.

\section{Study limitations}

The limitation of this study is related to the use of MeSH descriptors and keywords not recognized as terms used in the national literature, which may have resulted in only one Brazilian study in this review.

\section{Contributions to the nursing field}

The results of this integrative review will help health professionals, especially nursing professionals, reflect on the importance 
of analyzing real perceptions of patients in an induced coma, considering adjustments to patient care, aiming to ensure more personalized care with higher quality.

\section{FINAL CONSIDERATIONS}

This integrative review identified scientific evidence regarding patients' perceptions during intensive treatment and ICU stay, providing nursing knowledge of experiences with patients' perceptions while sedated and in the intensive care unit, measurement of delirium in the ICU and implications related to how families experience this critical period.
Communication challenges were observed between ICU nurses and patients in critical condition and an induced coma, showing gaps in the measurement of perceptions and signs from the patients and, above all, in the analysis of such perceptions and signs to improve nursing care in a comprehensive and individualized way.

Considering the above, an instrument should be developed with a proper methodology to evaluate the real perception of patients after an induced coma.

This theme needs further studies addressing the aspects of perceptive ability and its classification in the patients' perspective to fulfill the demands identified in the literature.

\section{REFERENCES}

1. Cabral FA, Apolinário A, Pompeu SMAA, Pompeu JE. Estimulação multissensorial em pacientes comatosos: uma revisão da literatura. Mundo Saúde. 2008;32(1):64-9.

2. National Institute of Neurological Disorders and Stroke. Coma Information Page: what research is being done? [Internet]. [place unknow]: National Institute of Neurological Disorders and Stroke; 2018 [cited 2017 Dec 20];. Available from: https://www.ninds.nih.gov/Disorders/ All-Disorders/Coma-Information-Page

3. Basto PAS, Soares YO, Oliveira HS, Gonçalves HS, Balestra LF, Gardenghi G. [Repercussions of sedation in hospitalized patients in intensive care units: a systematic review]. ASSOBRAFIR Ciênc [Internet]. 2014 [cited 2017 Dec 22];5(2):59-72. Available from: http://www.uel.br/ revistas/uel/index.php/rebrafis/article/view/17287/14805 Portuguese.

4. Pereira JM, Barradas FJR, Sequeira RMC, Marques MCMP, Batista MJ, Galhardas M, et al. [Delirium in critically ill patients: risk factors modifiable by nurses]. J Nurs Refer [Internet]. 2016 [cited 2018 Jan 15];4(9):29-36. Available from: http://dx.doi.org/10.12707/RIV16006 Portuguese.

5. Mori S, Takeda Jr T, Carrara FSA, Cohrs CR, Zanei SSV, Whitaker IY. Incidence and factors related to delirium in an intensive care unit. Rev Esc Enferm USP [Internet]. 2016 [cited 2018 Jan 15];50(4):585-91. Available from: http://dx.doi.org/10.1590/S0080-6234201600000500014

6. American Psychiatric Association. DSM-5: manual diagnóstico e estatístico de transtornos mentais. 5 ed. Porto Alegre: Artmed; 2015.

7. Ruedell LM, Beck CLC, Silva RM, Lisboa RL, Prochnow A, Prestes FC. [Interpersonal relationship between nursing professionals and families in the intensive care unit: a bibliographical study]. Cogitare Enferm [Internet]. 2010 [cited 2018 Jan 15];15(1):147-52. Available from: http:// revistas.ufpr.br/cogitare/article/view/17186/11321 Portuguese.

8. Costa JB, Marcon SS, Macedo CRL, Jorge AC, Duarte PAD. Sedation and memories of patients subjected to mechanical ventilation in an intensive care unit. Rev Bras Ter Intensiva [Internet]. 2014 [cited 2017 Dec 22];26(2):122-129. Available from: https://doi. org/10.5935/0103-507X.20140018

9. Mendes, KDS, Silveira, RCCP, Galvão CM. [Integrative literature review: a research method to incorporate evidence in health care and nursing]. Texto Contexto Enferm [Internet]. 2008 [cited 2017 Dec 22];17(4):758-64. Available from: http://dx.doi.org/10.1590/S010407072008000400018 Portuguese.

10. Melnyk BM, Fineout-Overholt E. Evidence based practice in nursing \& healthcare: A guide to best practice. 2th ed. Philadelphia: Wolters Kluwer Health, Lippincot Williams \& Wilkins; 2011.

11. Moher D, Liberati A, Tetzlaff J, Altman DG, PRISMA Group. Preferred reporting items for systematic reviews and meta-analyses: the PRISMA statement. PLoS Med [Internet]. 2009 [cited 2017 Nov 20]; 6(7):e1000097. Available from: https://doi.org/10.1371/journal.pmed.1000097

12. Ursi ES, Galvão CM. [Perioperative prevention of skin injury: an integrative literature review]. Rev. Latino-Am Enfermagem [Internet]. 2006 [cited 2017 Dec 22];14(1):124-31. Available from: http://dx.doi.org/10.1590/S0104-11692006000100017 Portuguese.

13. Svenningsen $\mathrm{H}$, Egerod I, Dreyer P. Strange and scary memories of the intensive care unit: a qualitative, longitudinal study inspired by Ricoeur's interpretation theory. J Clin Nurs [Internet]. 2016 [cited 2017 Dec 22];25(19-20):2807-15. Available from: https://doi.org/10.1111/ jocn. 13318

14. Fink RM, Makic MB, Poteet AW, Oman KS. The ventilated patient's experience. Dimens Crit Care Nurs [Internet]. 2015 [cited 2017 Dec 22];34(5):301-8. Available from: https://doi.org/10.1097/DCC.0000000000000128

15. Whitehorne K, Gaudine A, Meadus R, Solberg S. Lived experience of the intensive care unit for patients who experienced delirium. Am J Crit Care [Internet]. 2015 [cited 2017 Dec 22];24(6):474-9. Available from: https://doi.org/10.4037/ajcc2015435

16. Clukey L, Weyant RA, Roberts M, Henderson A. Discovery of unexpected pain in intubated and sedated patients. Am J Crit Care. [Internet] 2014 [cited 2017 Dec 22];23(3):216-20 Available from: https://doi.org/10.4037/ajcc2014943

17. Ewens B, Champman R, Tulloch A, Hendricks JM. ICU survivors' utilisation of diaries post discharge: A qualitative descriptive study. Aust Crit 
Care [Internet]. 2014 [cited 2017 Dec 22];27(1):28-35. Available from: https://doi.org/10.1016/j.aucc.2013.07.001

18. Meriläinen $M$, Kyngäs $H$, Ala-Kokko T. Patient's interactions in an intensive care unit and their memories of intensive care: a mixed method study. Intensive Crit Care Nurs [Internet]. 2013 [cited 2017 Nov 20];29(2):78-87. Available from: https://doi.org/10.1016/j.iccn.2012.05.003

19. Engström Å, Nyström N, Sundelin G, Rattray J. People's experiences of being mechanically ventilated in an ICU: a qualitative study. Intensive Crit Care Nurs [Internet]. 2013 [cited 2017 Nov 20];29(2):88-95. Available from: https://doi.org/10.1016/j.iccn.2012.07.003

20. Svenningsen $\mathrm{H}$. Associations between sedation, delirium and posttraumatic stress disorder and their impact on quality of life and memories following discharge from an intensive care unit. Dan Med J [Internet]. 2013 [cited 2017 Nov 20];60(4):B4630. Available from: https://www. researchgate.net/publication/236653057_Associations_between_sedation_delirium_and_post-traumatic_stress_disorder_and_their_ impact_on_quality_of_life_and_memories_following_discharge_from_an_intensive_care_unit

21. Åkerman E, Ersson A, Feidlund B, Samuelson K. Preferred content and usefulness of a photodiary as described by ICU patients: a mixed method analysis. Aust Crit Care [Internet]. 2013 [cited 2017 Nov 20];26(1):29-35. Available from: https://doi.org/10.1016/j.aucc.2012.04.002

22. Samuelson KAM. Unpleasant and pleasant memories of intensive care in adult mechanically ventilated patient - findings from 250 interviews. Intensive Crit Care Nurs [Internet]. 2011 [cited 2017 Nov 20];27(2):76-84. Available from: https://doi.org/10.1016/j. iccn.2011.01.003

23. Storli SL, Lind R. The meaning of follow-up in intensive care: patients' perspective. Scand J Caring Sci [Internet]. 2009 [cited 2017 Nov 20];23(1):45-56. Available from: https://doi.org/10.1111/j.1471-6712.2007.00589.x

24. Engström Å, Grip K, Hamrém M. Experiences of intensive care unit diaries: touching a tender wound. Nurs Crit Care [Internet]. 2009 [cited 2017 Dec 22];14(2):61-7. Available from: https://doi.org/10.1111/j.1478-5153.2008.00312.x

25. Roberts BL, Rickard CM, Rajbhandari D, Reynolds P. Factual memories of ICU: recall at two years post-discharge and comparison with delirium status during ICU admission - a multicenter cohort study. J Clin Nurs [Internet]. 2007 [cited 2017 Dec 22];16(9):1669-77. Available from: http://doi.org/10.1111/j.1365-2702.2006.01588.x

26. Roulin MJ, Hurst S, Spirig R. Diaries written for ICU patients. Qual Health Res [Internet]. 2007 [cited 2017 Dec 22];17(7):893-901. Available from: http://doi.org/10.1177/1049732307303304

27. Soares LG, Reis MR, Soares LG. Humanização na UTI: dificuldades encontradas para sua implementação uma revisão integrativa. Voos Rev Polidisciplinar Eletrôn Fac Guairacá [Internet]. 2014 [cited 2017 Dec 22];6(1):70-86. Available from: http://www.revistavoos.com.br/seer/ index.php/voos/article/view/263/263-1106-1-PB

28. Olding M, McMillan SE, Reeves S, Schmitt MH, Puntillo K, Kitto S. Patient and family involvement in adult critical and intensive care settings: a scoping review. Health Expect [Internet]. 2016 [cited 2017 Dec 22];19(6):1183-1202. Available from: http://doi.org/10.1111/hex.12402

29. van Tol DG, Kouwenhoven P, van der Vegt B, Weyers H. Dutch physicians on the role of the family in continuous sedation. J Med Ethics [Internet]. 2015 [cited 2017 Dec 22];41(3):240-4. Available from: http://doi.org/10.1136/medethics-2013-101624

30. Trzepacz PT, Meagher DJ. Aspectos neuropsiquiátricos do delirium. In: Yudofsky SC, Hales RE. Fundamentos de neuropsiquiatria e ciências do comportamento. Porto Alegre: Artmed, 2014. p. 159-228.

31. Ringdal M, Johansson L, Lundberg D, Bergbom I. Delusional memories from the intensive care unit - experienced by patients with physical trauma. Intensive Crit Care Nurs [Internet]. 2006 [cited 2017 Dec 22];22(6):346-54. Available from: http://doi.org/10.1016/j.iccn.2006.03.001

32. Grossbach I, Stranberg S, Chalan L. Promoting effective communication for patients receiving mechanical ventilation. Crit Care Nurse [Internet]. 2011 [cited 2017 Dec 22];31(3):46-60. Available from: http://doi.org/10.4037/ccn2010728 